\title{
Sharia Life Insurance: Legal Basis and Operational Systems
}

\author{
Munawir Idris $^{1 *}$ and Darminto Hartono Paulus ${ }^{2}$ \\ ${ }^{1}$ Fakultas Hukum, Universitas Negeri Gorontalo, Gorontalo-Indonesia \\ ${ }^{2}$ Fakultas Hukum, Universitas Diponegoro, Semarang-Indonesia \\ *batudaa92@gmail.com
}

Published: 30/03/2020

How to cite (in APA style):

Idris, M., \& Paulus, D. H. (2020). Sharia Life Insurance: Legal Basis and Operational Systems. Jurnal Hukum Prasada, 7 (1), 45-52. https://doi.org/10.22225/jhp.7.1.1342.45-52

\begin{abstract}
Islamic life insurance is a non-bank financial institution that is used by the Muslim community as a medium in anticipating risks that might arise in the future. So that people make insurance, especially sharia life insurance as an alternative in dealing with future risks related to one's life. This study aims to determine the legal basis for sharia life insurance and its operating system as a forum for information for Muslim communities in Indonesia. In this study, the author uses the doctrinal research method in which the approach used is the regulatory approach (Islamic law) and the conceptual approach. This research prioritizes secondary data in its management such as primary legal materials, secondary legal materials, and tertiary legal materials. This study shows the origin of Islamic insurance is derived from the traditions of the Arab community at the time of the Prophet Muhammad, called Akilah. If someone dies (killed) by someone, then the family of the murderer is obliged to pay blood money (diyat) to the heirs of the victim. The blood money was collected from murderous families and then handed over to the heirs of the victims. This tradition later developed into Islamic insurance known today. Sharia insurance operational system is to use two contracts, namely Tabarru contract and mudharabah contract. With the existence of these two contracts, the elements of gharar, maysir and riba can be removed.
\end{abstract}

Keyword: Legal basis, operational systems, sharia life insurance

\section{INTRODUCTION}

Islamic insurance grows and develops along with the growth and development of Islamic banking. Nevertheless, many people do not understand what and how Islamic insurance is. This requires comprehensive information to provide understanding to the general public so that there is no mistaken understanding of Islamic insurance (Puspitasari, 2011).

Islamic Insurance or better known as Sharia Insurance is one of the non-bank financial instruments that is used as a medium for the public in anticipating risks that may occur in the future (Disemadi, 2019). Sharia insurance is an alternative for the community, especially the Muslim community, which forbids conventional insurance (Ismanto, 2014).

Sharia Insurance in Indonesia, since it was developed in 1994, has not experienced significant development. The growth of Islamic insurance from time to time has not been able to catch up with let alone match conventional insurance. In terms of the presence of Islamic insurance, it is enough to get a positive response from the community, not only by the Muslim community but also by non-Muslims. Thus, the true Islamic insurance in Indonesia experienced rapid growth (Supriyatni \& Fauji, 2017).

Islamic insurance consists of life insurance and general insurance. The difference 
between the two lies in the object coverage. Sharia life insurance, the coverage is human while general Islamic insurance, the object of coverage is property, for example; house, car, boat and other property (Saniatusilma \& Suprayogi, 2015). In addition to the different objects, the mechanism of life insurance and general Islamic insurance is also different. Nevertheless, both types of sharia insurance have the same principle, namely please help (ta'awun).

The principle of helping which is the main goal of sharia life insurance is the implementation of Firman Allah SWT, in the Qur'an letter al Maidah verse 2: "dan tolong menolonglah kamu dalam (mengerjakan) kebaikan dan takwa, dan jangan tolong menolong dalam berbuat dosa dan pelanggaran". That is, every human being is encouraged to help one another in terms of good but not help in things that are bad and violations.

Sharia life insurance participants help each other and protect through contributions to the Tabarru Fund. Tabarru fund is a collection of benevolent funds from money contributed by Sharia Life Insurance participants who agree to help each other if there is a risk between them. These funds are then managed according to Sharia principles and under the supervision of the Sharia Supervisory Board (DPS) to face certain risks (Antonio, 1994)

If there is a risk to the participant, insurance benefits will be paid from the Tabarru Fund. This concept is also known as risk-sharing (Ismanto, 2014). Meanwhile, in conventional life insurance, the customer pays many premiums for the protection he buys to the insurance company. If there is a risk to the customer, the life insurance company will provide many insurance benefits. This concept is also known as risk transfer (Shomad, 2017).

There are some fundamental differences between Sharia Life Insurance and Conventional Life Insurance in terms of contracts, fund ownership, underwriting surplus, investment management, and insurance supervision. In Sharia Life Insurance, several types of transactions must be avoided namely gharar or uncertainty, riba or additional and maysir or gambling. So, Customer' funds in Sharia Life Insurance, especially unit links, will not be invested in matters that are contrary to Islamic Sharia, for example, financial and banking products with the concept of riba, cigarettes, and liquor (Budiyono, 2019).

Sharia life insurance is very good, especially in the context of preparing many funds to be given to heirs in the event of a risk of death. Especially if it happens to a family backbone. You can imagine how the sustainability of the lives of those left behind. They will certainly face economic difficulties or at least they will have to work hard to get their daily living expenses. In another case if someone has Islamic life insurance, at least can help the family left behind, inheritance in the form of insurance money can be used as education costs or used as business capital (Antonio, 1994)

However, in general, Indonesian people have not yet realized the importance of having financial planning in the form of insurance. They prefer investments in the form of objects, for example; land, gold, and property.

Insurance is not yet a choice or priority in preparing inheritance. Apart from the low awareness of the public to have a sharia life insurance program, this article will be explained the legal basis, concepts and operational systems of sharia life insurance. This is important to say because this is a starting point in increasing public understanding of Islamic life insurance (Shomad, 2017). This article is expected to provide a complete understanding of sharia life insurance, including understanding the differences with conventional insurance.

Previous research related to the current research was by Novi Puspitasari in 2011, the focus of this study was the history and development of Islamic insurance as well as the difference with conventional insurance (Puspitasari, 2011). Then by Usawatun Hasanah in 2013, this research focused on insurance from the perspective of Islamic law (Hasanah, 2013). Although previous researches have the theme of sharia insurance, there is a difference in the focus of the current research, which is that the current research focuses more based on Islamic law and operational systems regarding sharia life insurance. 


\section{METHOD}

This research is designed by using legal-normative (doctrinal) research methods. The study was conducted with a regulatory approach (Islamic law) and a conceptual approach. The data used are secondary data which consists of primary legal materials such as books, secondary legal materials such as journals related to sharia life insurance and tertiary legal materials in the form of dictionaries. Then, the data are collected according to the criteria and processed by qualitative descriptive analysis techniques.

\section{RESULTS AND DISCUSSION}

\section{Definition And History Of Sharia Insurance}

Before putting forward the notion of Islamic life insurance, the authors first state the notion of insurance in general. The word insurance comes from the Dutch language, assurantie which in Dutch law is called Verzekering which means coverage. From the term assurantie then born the term assuradeur for the guarantor and greassureerde for the insured (Puspitasari, 2011).

Mark R. Greene, as quoted by Muhammad Syakir Sula in his book Asuransi Syariah; Life and General, define insurance as "an economic institution th at reduces risk by combining under one management and group of objects so situated that the aggregate accidental losses to which the group is subject become predictable within narrow limits" (Sula, 2004).

In Indonesia, the definition of insurance by default has been mentioned in Law No. 2 of 1992 concerning Insurance Business. The Law states that insurance or coverage is an agreement between two or more parties. One party is called the guarantor and the other party is called the insured. The insurer binds himself to the insured by receiving several insurance premiums, to provide compensation to the insured due to loss, damage or loss of expected profits. Or legal liability to third parties that may be suffered by the insured, arising from an uncertain event; or to provide a payment based on the life or death of an insured person (Hasanah, 2013).

From the above definition, it can be understood that insurance is a contract or agreement between two or more parties to anticipate risks that might occur in the future, but the exact time is unknown. Contracting parties in insurance are referred to as the guarantor and the insured. The insured object, as referred to in Law No. 2 of 1992 above, are the risks of loss to assets, businesses, and human lives. That understanding includes what is referred to as general insurance and life insurance. Insurance in the above sense is categorized as conventional insurance (Antonio, 1994).

Apart from conventional insurance, some are categorized as Sharia Insurance. Sharia Insurance is an effort to protect each other and help one of several people/parties through investments in the form of assets and/or tabarru 'which provides a pattern of return to face certain risks through contracts that are by sharia. Based on this definition it can be understood that the essence of Islamic insurance is mutual protection and help (ta'awun) (Sula, 2004). Thus it can be said that Islamic insurance is very relevant to the teachings or values of life together (community) namely togetherness. One community member always helps other community members. This becomes even more important if it is associated with ukhuwah Islamiyah (brotherhood of fellow Muslims) (Said \& Herman, 2015).

In Sharia Insurance, between the guarantor and the insured are not separate. Participants become the guarantor and at the same time become the insured party. Because in principle please help. The insurance company only acts as the operator who receives the mandate from the participant to manage the contribution deposited by the customer. This is different from Conventional Insurance that uses the principle of buying and selling. Insurance companies as insurers and participants as insured (Hasanah, 2013).

The origin of Sharia Insurance is derived from the culture of the Arab tribes in the time of the Prophet Muhammad, called Akilah. In the Dictionary of Islam compiled by Thomas Patrick, as quoted by Bambang Trim, it is explained that if one member of the tribe is killed by another tribe, the victim's family will be paid blood money (diyat) as 
compensation by the closest relative of the killer. The killer's closest relatives are usually called Akilah as payers of blood money in the name of the killer. It was further explained that Al-Aqilah means mutual responsibility and responsibility for the family. In the case of the murder of a family member, the heirs of the victim will get blood money paid by the immediate family member from the killer. The funds used to pay the diyat were collected in cooperation by family members involved in the murder.

From the above descriptions, it can be concluded that the origin of Sharia Insurance is the protection of one's life, which is now referred to as Sharia Life Insurance (Puspitasari, 2011). Another case with Conventional Insurance was born in Western Europe in the middle ages. Initially, insurance was intended to protect property, namely fire insurance (Shomad, 2017). Furthermore, in the 13th and 14th centuries, marine transportation insurance was born (Sula, 2004). Conventional life insurance began to be known in the 19th century. The basic concept of Islamic insurance is between the insurer and the insured is not separate. Participants are insured as well as the guarantor. As the insured, the participant or his heir will receive payment for the loss of economic value experienced as a result of being exposed to the risk of illness, disability due to an accident or death (Antonio, 1994).

These payment funds are taken from a pooled fund of all participants called the Tabarru Fund. Each participant contributes (in conventional insurance called a premium) by the provisions stipulated in the insurance company. In this condition, the participant functions as a guarantor. Because their funds are used to pay claims if there are participants who are at risk. If so, what is the position of the Islamic insurance company? Sharia insurance companies only play the role of the operator (manager) in charge of administering membership data, managing risks, managing tabarru funds' and paying claims as promised. As compensation for the work, the insurance company obtains a fee (wage) and or profit share from the management of funds collected from participants.

\section{Legal Basis Sharia Insurance}

Naturally, some people try to minimize the risk of life and property they have. To minimize the risk of loss, various insurance companies have emerged that offer a sense of security, the question being is whether insurance is permissible under Islamic law? Abu Zahrah's opinion was quoted by Husain Syahatah, collective insurance (ta āwun) is permissible (halal). According to him, this type of insurance is the implementation of a helping attitude in virtue and piety that is ordered by Allah SWT (Hasanah, 2013).

Insurance was also applied at the beginning of Islam in the form of brotherhood between the Muhajirin and the Ansar. In the Qur'an, there is indeed no clear and explicit verse regarding the issue of insurance (Shomad, 2017). Even so in verse al-Qur'an still mentions the values that have to do with insurance issues, such as help, help, cooperation and enthusiasm to protect against what will happen in the future. In surah Al-Ma'idah Verse 2 states that humans were created in the world not alone but together with other humans. Humans are social creatures who cannot live alone but must be together with other humans who live in society. Humans must help each other with fellow human beings. Islamic insurance, in essence, is mutual help between each other. Helping people's lives will be easier and more prosperous because no one knows their destiny in the future. This is by the word of Allah SWT, surah Luqman verse 34: "Sesungguhnya Allah, hanya pada sisi-Nya sajalah pengetahuan tentang hari kiamat; dan Dialah yang menurunkan hujan dan mengetahui apa yang ada dalam rahim. Dan tiada seorang pun yang dapat mengetahui (dengan pasti) apa yang akan diusahakannya besok; dan tiada seorang pun yang dapat mengetahui di bumi mana ia akan mati. Sesungguhnya Allah Maha Mengetahui lagi Maha Mengenal".

The verse stated clearly that, human knowledge is very limited, usually humans can only plan, while what will happen in the future he does not know. As a human being, he is only given the ability to manage his life and lives to achieve happiness. One way to achieve happiness is to prepare provisions (protection) for the benefit of the future, so that anything that is of negative value, in the form of disaster, accident, fire or death, can be minimized (Budiyono, 2019). In the Qur'an, Allah SWT reminds people to prepare to face difficult times 
in the future, and this is one of the principles that serve as a benchmark for the value of Islamic insurance philosophy, in addition to being in the form of a spirit of help and help and work same. The warning is in the Koran surah Yusuf verses 46-49, which means more or less as follows: "Yusuf, hai orang yang amat dipercaya, terangkanlah kepada kami tentang tujuh ekor sapi betina yang gemuk-gemuk yang dimakan tujuh ekor sapi betina yang kuruskurus dan tujuh bulir (gandum) yang hijau dan (tujuh) yang kering agar aku kembali kepada orang-orang itu, agar mereka mengetahuinya." Dalam ayat berikutnya, yakni Surat Yusuf ayat 47, Yusuf berkata: "Supaya kamu bertanam tujuh tahun (lamanya) sebagaimana biasanya; maka yang kamu tuai hendaklah kamu biarkan dibulirnya kecuali sedikit untuk kamu makan". Dalam ayat 48 disebutkan: "Kemudian sesudah itu akan datang tujuh tahun yang amat sulit, yang menghabiskan apa yang kamu simpan untuk menghadapinya (tahun sulit), kecuali sedikit dari (bibit gandum) yang kamu simpan"; Dalam surat yang sama ayat 49 disebutkan: "Kemudian setelah itu akan datang tahun yang padanya manusia diberi hujan (dengan cukup) dan di masa itu mereka memeras anggur". Dalam Surat al-Hasyr ayat 18 Allah juga berfirman,: "Hai orang-orang yang beriman, bertakwalah kepada Allah dan hendaklah setiap orang memperhatikan apa yang telah dibuat untuk hari esok (akhirat). Dan bertakwalah kepada Allah sesungguhnya Allah Maha Mengetahui apa yang kamu kerjakan".

It was stated at the beginning of the discussion that insurance had also been practiced by the Messenger of Allah and his Companions. This shows that according to Islamic law, insurance is permissible as long as practices are carried out such as contract, fund management, investment funds, ownership of funds, elements of premiums, and other matters relating to operational techniques that are still based on the Qur'an and al- Sunnah. This issue must be considered because general principles in mu 'amalah also underlie Islamic insurance (Sula, 2004).

The principles contained in Islamic insurance are as follows:

Tawhid (piety). If you look at the verses of the Qur'an about mu'amalah, it will be seen that Allah SWT always calls upon His people so that $m u$ 'amalah which he does leads to the submission of Allah SWT (Budiyono, 2019). A Muslim when buying and selling, renting and employing, exchanging with others in property or various uses, he is always subject to the rules of Allah SWT in his mu'amalah. He will not try with something unlawful such as riba, hoarding, wrongdoing, cheating, gambling, stealing, bribing and accepting bribes. Allah SWT puts the principle of tawhid (piety) as the main principle in mu'amalah. Therefore, all activities in mu'amalah must always direct the perpetrators to increase piety to Allah SWT.

The second principle in mu'amalah is to be fair. Quite a lot of verses in the Qur'an command humanity to be fair to anyone, including themselves. Allah SWT loves those who do justice and hate those who do wrong, even curse them. Fairness is needed when determining the ratio of muï arabah, musyawarah, wakalah, wadi'ah and so on, in Islamic banks. Fairness is also needed when Islamic insurance (Islamic insurance) determines the profit-sharing in the surplus underwriting and the investment profit sharing between the company and participants. For this reason, transparency in banking and Islamic insurance becomes very important (Shomad, 2017).

Prohibition of committing tyranny. Injustice is the opposite of the principle of justice. Therefore, Islam is very strict in paying attention to violations of wrongdoing, enforcing the prohibition against them, harsh criticism of wrongdoers, threats against them with the most severe punishment in the world and the hereafter (Ismanto, 2014). In surah al-Syura verse 40 Allah SWT says: "Sungguh, Dia tidak menyukai orang-orang yang zalim", and in surah al-Baqarah verse 258 Allah SWT says: "Allah tidak memberikan petunjuk kepada orangorang yang zalim".

Al-Ta'awun. The fourth principle which is the basis of ethics in mu'amalah is Islamic is ta'awun. Ta'awun is one of the main principles of mu'amalah interactions. Even ta'awun can be the foundation in building a community system, the rich pay attention to the poor in terms of financial needs, and the poor help the rich in power or other matters. Ta'awun is the core of the takaful concept, where one participant and other participants take risks, that is, through the Tabarru funding mechanism "with the correct contract" Aqd Takafulli or 'Aqd 
Tabarru'. Takaful can be a solution so that people escape poverty because the attention of the rich to the poor has been regulated in sharia. Do not let wealth only revolve around rich people, around only tycoons (Antonio, 1994).

Al-Amanah (trustworthy/honest). According to Yusuf al-Qaradlawi, among the most important transaction values in business is al-amānah or 'honesty'. It is the culmination of the morality of faith and the most prominent characteristics of believers. Honesty is a characteristic of the Prophets. Without honesty, religious life will not stand tall and world life will not go well. Conversely, lying is a branch of hypocrisy and is one of the characteristics of hypocrites.

Al-Rida (likes and likes) In the Qur'an, Allah says, "Hai orang-orang yang beriman, janganlah kamu saling memakan harta sesamamu kecuali dengan jalan perniagaan yang berlaku dengan suka sama suka di antara kamu". According to Abul A'la al-Maududi, the verse has set two cases as a legal condition of trade. First, trade should be carried out with equal love between the two parties. Second, let the benefits of one party not stand based on the loss of the other party. Here is the importance of the principle of al-rida in mu'amalah. Because, without being based on pleasure, then the entire contract in mu'āmalah will be canceled. As such, the position of the principle of liking and liking is very important in the contracts made in mu'amalah which are based on sharia law. According to Fathi Ahmad Abdul Karim, the contracts in Islam will not be perfect unless they apply with the principle of liking and agreeing between the two parties to the contract. Islam has carried out perfect maintenance and guidance in the framework of implementing the principle of pleasure to both parties by requiring both parties to carry out the contract to be equally (Shomad, 2017).

Stay away from garar, maisir, and riba. The most important principle in Islamic mu'amalah especially for Islamic Financial Institutions (LKS) is to stay away from riba, garar, and maisir. In the Qur'an, Allah SWT says: "Allah menghalalkan jual beli dan mengharamkan riba". Riba is taking other people's property without any balance. The meaning of maisir is gambling (Sula, 2004). According to Husain Hamid Hasan, the gambling contract is a Garar contract, because each party who gambles determines the contract amount of money taken or given, and determine the amount given can be determined later depending on an uncertain event, that is if the win is known the amount received and if you lose, you will know the amount given.

\section{Sharia Life Insurance Operational System}

As explained in the previous section, the basic principles of sharia insurance are ta'awun or help (Said \& Herman, 2015). The concept of a separate insured and guarantor, as in conventional insurance, does not apply in sharia insurance. Starting from the principle of ta'awun and mutual bearing, the operational system of sharia life insurance is certainly different from the conventional life insurance operating system. The operational system of sharia life insurance always avoids the existence of elements of gharar, maisir, and riba.

To avoid the existence of elements of gharar, maysir, and usury, then in sharia life insurance uses two contracts, namely Tabarru contract or also commonly called takafuli contract and mudharabah contract (profit sharing) (Said \& Herman, 2015). In its operation, Islamic insurance prepares a special account as a help account fund or a tabarru account 'which accommodates contributions made by all participants who have been intended to help fellow participants (Puspitasari, 2011).

Each participant contributes to the manager (the company) and then the manager will allocate it to two accounts, i.e. tabarru 'or charity (joint account) and participant's account. If a participant is exposed to the risk of illness, accident or death, the claim will be paid or taken from the tabarru account. Through this mechanism, it is clear that each participant contributes or gives to the participants at risk (Sula, 2004).

A clearer explanation regarding this is given by Shafi'i. Antonio. According to Shafi'i Antonio, the gharar problem in sharia life insurance can be eliminated because the contract used is a takafuli agreement or a contract of mutual assistance and guarantee. "In the concept of Islamic insurance, all insurance participants become helpers and guarantors of 
each other. If a participant $(A)$ dies, participants $(B),(C)$, to $(Z)$ also help, vice versa" (Antonio, 1994).

As an illustration, an insurance participant contributes to Rp. 2 million / month for 10 years. After being counted by the underwriting party, the participant is determined to get Sum Assured of Rp. 300 million if you die. However, the participant died when his participation had been running for 4 years. Thus, the participant has only deposited funds in the amount of Rp. 96 million. When he dies, his heir will receive compensation of Rp. 300 million. The question is, where does the Rp. 300 million was given to the heirs while the funds were only Rp. 96 million?. The answer is funds of Rp. 300 million was taken from Tabarru's cash fund or funds collected from all participants. Aren't the participants in this case the heirs lucky and the company is losing money? Of course not, because Tabarru funds' are grants or donations from all participants who are intended to help if there are participants who are at risk of illness, accident or death. These funds do not belong to the company but are shared by participants. Insurance companies only accept the mandate to manage these funds.

Thus in Islamic insurance, there is no profit and no loss. What exists is mutual assistance to help each other through the mechanism of collecting tabarru funds' as benevolent funds. Islamic insurance is one way for someone to help others if exposed to the risk of life.

\section{CONCLUSION}

Insurance is one of the institutions that was practiced before Islam came, commonly known as al-aqilah. The institution was later approved by the Messenger of Allah to be part of Islamic Law as outlined in the Medina Charter and further developed during the time of Khulafa al-Rashidin especially at the time of Umar bin Khattab. Despite the ups and downs, this institution is constantly being developed in the Islamic world. Islamic law views insurance as a social phenomenon formed based on mutual assistance and humanity. Bear each other in Islamic law is emphasized. The things above show that Islamic Insurance is part of Islamic Law. The development of Islamic insurance or Islamic insurance which is very fast in various parts of the world including in Indonesia shows that Islamic insurance is indeed quite attractive to the public, especially Muslims.

Sharia insurance operational system is to use two contracts, namely Tabarru contract and mudharabah contract. With the existence of these two contracts, the elements of gharar, maysir, and riba can be removed. Islamic life insurance companies create two accounts to accommodate and develop participant contribution funds. One account to hold grants or donations is called a tabarru account 'and another account to hold participant funds as investment funds. If there are participants who are at risk of illness, accident or death, the Islamic life insurance company will pay compensation to the heirs taken from the tabarru account.

\section{REFERENCES}

Antonio, M. (1994). Asuransi Dalam Perspektif Islam. Jakarta: Syarikat Takaful Indonesia.

Budiyono, T. (2019). Penjamin Simpanan dari Waktu ke Waktu (Studi Penjamin Simpanan di Indonesia). Refleksi Hukum: Jurnal IImu Hukum. 3(2), 129-144. Retrieved from https:/l doi.org/10.24246/jrh.2019.v3.i2.p129-144

Disemadi, H. S. (2019). Kontrak Build Operate Transfer Sebagai Sarana Mewujudkan Kesejahteraan Rakyat. Jurnal Komunikasi Hukum (JKH), 5(2), 126-138. Retrieved from https://ejournal.undiksha.ac.id/index.php/jkh/article/view/18419

Hasanah, U. (2013). Asy-Syir'ah Asuransi Dalam Perspektif Hukum Islam. Jurnal IImu Syari' Ah Dan Hukum, 47(1), 1-31. Retrieved from http://dx.doi.org/10.14421/asy-syir'ah.2013.\%25x

Ismanto, K. (2014). Penerapan Prinsip-Prinsip Syariah Pada Perjanjian Asuransi Syariah Di Ro Takaful Keluarga Pekalongan. Jurnal Hukum Islam, 12(1), 103-116. Retrieved from https:// doi.org/10.28918/jhi.v12i1.530

Puspitasari, N. (2011). Sejarah Perkembangan Asuransi Islam serta Perbedaanya dengan Asuransi Konvensional. JEAM: Jurnal Ekonomi Akuntansi dan Manajemen, 10(1), 35-47. Retrieved from https://jurnal.unej.ac.id/index.php/JEAM/article/view/1202 
Said, M., \& Herman, W. (2015). Perjanjian (Kontrak) Asuransi Modern Menurut Hukum Islam (Studi Pemikiran Muhammad Muslehuddin. Jurnal Hukum Islam, XV(1), 214-229. Retrieved from https://www.neliti.com/id/publications/56125/perjanjian-kontrak-asuransi-modern-menuruthukum-islam-studi-pemikiran-muhammad

Saniatusilma, H., \& Suprayogi, N. (2015). Manajemen Risiko Dana Tabarru'PT. Asuransi Jiwa Syariah Al Amin. Jurnal Ekonomi Syariah Teori Dan Terapan, 12(2).Retrieved from http:/l dx.doi.org/10.20473/vol2iss201512pp\%25p

Shomad, A. (2017). Hukum Islam: Penormaan Prinsip Syariah dalam Hukum Indonesia. Jakarta: Kencana.

Sula, M. (2004). Asuransi Syariah; Life and General. Jakarta: Gema Insani Press, 200.

Supriyatni, R., \& Fauji, A. A. (2017). Penerapan Prinsip Syariah Pada Lembaga Jasa Keuangan Perasuransian Di Indonesia. Jurnal Jurisprudence, 7(1), 29-39. Retrieved from https:// doi.org/10.23917/jurisprudence.v7i1.4352 